\title{
THE EFFECT OF INCREASED SOWING SPEED ON SOWING EFFICIENCY AND YIELD LOSS IN MAIZE AND SUNFLOWER IN HUNGARY
}

\author{
Gergely Tóth, Iván Czakó \\ Researchers at Discovery Research and Development Center Ltd., Budapest, Hungary
}

Article DOI: https://doi.org/10.36713/epra7195

DOI No: 10.36713/epra7195

\begin{abstract}
In Hungary the spring time sowing of maize and sunflower is very critical, as the optimal time window is short. The soil moisture decreases rapidly, and the unstable weather conditions create even more difficult conditions for the farmers, but the sowing quality and the plant density have strong effects on the yield. In our experiments we explored the possibility of speeding up the process of sowing, as a solution to this problem, and found that compared to the baseline, the increased speed caused perceptible quality problems, and density loss. These problems may lead to serious yield and economical loss, so the increased sowing speed is not an advisable option.
\end{abstract}

ABSTRACT

\section{INTRODUCTION}

The two most important wide row crops in Hungary are maize and sunflower. The sown area of maize in Hungary has been exceeding 1 million hectares for several decades, our most important fodder crop. Sunflower has been the main oil crop and sown area in Hungary since the 1990s, and plays an important role in our diet. According to the data of the CSO, the harvested area of sunflower was around 350 thousand hectares in the 1990 s, by 2017 it had already reached 704 thousand hectares. (Hungarian Central Statistical Office, Summary data of agriculture, 2020)

The main characteristics of sowing are sowing time, row spacing, stem spacing, sowing depth and the amount of seed sown, which greatly influence the subsequent yield.Maize sowing time is affected by changes in soil temperature, it requires a soil temperature of 8 to $12^{\circ} \mathrm{C}$ to germinate, but recently, due to global warming, the soil temperature has already reached $10^{\circ} \mathrm{C}$ in the first half of April. (Berzsenyi et al., 1995) Therefore, our previous knowledge about the optimal sowing time needs to be re-evaluated. Today, the optimal sowing time is April 10 to May 2. Maize is sown with a pneumatic seed drill per row at a row spacing of 70-76.2 $\mathrm{cm}$ and a seed spacing of $16-22 \mathrm{~cm}$. The sowing depth is usually $5-6 \mathrm{~cm}$. (Antal et al., 2005) The quality of sowing includes the invariant stem distance, and the uniformity of sowing depth. Optimal sowing time and quality is crucial for reaching the potentially maximum yield. Of course, hybrids with shorter growing times have a wider optimal sowing time interval than hybrids with longer growing times. (Radics et al., 2012) Regression analysis for various sowing dates showed that maize sown between 1020th April gave the highest yield. (Árendás et al., 2012) Optimal plant density varies between 63$73000 \mathrm{plant} / \mathrm{ha}$, depending on the hybrid. (Berzsenyi et al., 2005) Others found that the optimal density being $70000 \mathrm{plant} / \mathrm{ha}$, the yield decreasing severly with decreased or increased density. (Kovács et al, 2016)

Optimal sowing time for sunflower is between 15th of April and 10th of May, it is sown usually with a pneumatic seed drill per row at a row spacing of 70-76.2 cm. The sowing depth is usually $4-6 \mathrm{~cm}$. (Radics et al, 2012) Agrotechnical factors have a great influence on the yield of sunflower hybrids. Optimal plant density regarding yield and oil content is $55000 \mathrm{plant} / \mathrm{ha}$ for most hybrids. (Szabó et al, 2007) Optimal sowing time, and density has a strong impact on yield and oil content, even the smallest deviation from the optimal value can cause serious yield loss. (Novák et al, 2013) 


\section{OBJECTIVES}

Due to the size of the area sown with maize and sunflower, the profitability of the agricultural sector and the output of gross domestic product depend to a large extent on the success of their cultivation. When growing an arable crop, sowing it at the optimal time and the precise execution of the sowing is a central point of crop production. Mistakes made during sowing cannot be corrected later. The grower is interested in the number of plants to which the maximum yield belongs. The main characteristics of sowing are row spacing, stem spacing, sowing depth and the amount of seed sown, which greatly influence the subsequent yield. We have plenty of research materials and practical experience on the optimal values of these parameters, but there is less talk in the literature about the exact choice of sowing speed, although it affects all the parameters that are the main characteristics of sowing. The quality of sowing also has a direct effect on germination, plant development dynamics, the necessary plant protection work and the quantity and quality of the crop. The number of plants planted and the number of plants actually germinated can be significantly different in practice if the sowing conditions were not appropriate. Due to increasing climatic extremes, farmers have less and less time intervals to get the propagating material into the soil at the right time, with optimal moisture. So one of the basic conditions for establishing successful sunflower and maize production is sowing done at the right time and quality.

Large-area crop species, area concentration, ever-larger implements, labor shortages, and increasingly extreme weather conditions combine to encourage farmers to increase sowing speeds to maintain optimal sowing times. However, this process jeopardizes the quality of the work and can thus lead to crop losses. To investigate this, we set up sowing speed experiments in the spring of 2020.

\section{METHODOLOGY}

The sowing speed experiment was set up in 5 different locations in Hungary. The five sites, which are well separated in terms of territory, were in the proximity of the settlements of Tura, Tápiószőlős, Hegykő, Simaság and Fertőd.

In the experiment, the effect of different sowing rates on sowing parameters was investigated. The set travel speeds were 10,12,14, 16 and $18 \mathrm{~km} /$ $\mathrm{h}$ in most cases. The 16 and $18 \mathrm{~km} / \mathrm{h}$ treatments were not set at all locations, as the seed drills used by farmers could no longer withstand this high forward speed, and their accuracy was drastically reduced.

The distance between the plants was measured later in the vegetation period. Plant spacing was checked in a distance of 5 meters in a total of three rows. Sowing depth was measured randomly at 2-2.5 meters. Later, the plant spacing was also checked by remote sensing with drone orthophotos.

\section{RESULTS}

The main purpose of setting up the experiment was to economically evaluate the time gained during sowing at elevated speeds and the resulting yield loss. The first table shows the plant distance results measured during the experiment.

\begin{tabular}{|c|c|c|c|c|c|}
\hline & $\begin{array}{r}\text { Maize } \\
\text { Tura } \\
\end{array}$ & $\begin{array}{c}\text { Sunflower } \\
\text { Tápiószőlős }\end{array}$ & $\begin{array}{c}\text { Sunflower } \\
\text { Simaság }\end{array}$ & $\begin{array}{c}\text { Silage Maize } \\
\text { Hegykő }\end{array}$ & $\begin{array}{l}\text { Maize } \\
\text { Fertőd } \\
\end{array}$ \\
\hline $\begin{array}{c}10 \\
\mathrm{~km} / \mathrm{h}\end{array}$ & 20,74 & 25,9 & 25,19 & 16,65 & 17,91 \\
\hline $\begin{array}{c}12 \\
\mathrm{~km} / \mathrm{h}\end{array}$ & 21,23 & 27,35 & 27,62 & 18,35 & 19,53 \\
\hline $\begin{array}{c}14 \\
\mathrm{~km} / \mathrm{h}\end{array}$ & 21,86 & 28,07 & 28,9 & 18,39 & 19,48 \\
\hline $\begin{array}{c}16 \\
\mathrm{~km} / \mathrm{h}\end{array}$ & 22,47 & 28,74 & & 17,44 & 19,2 \\
\hline $\begin{array}{c}18 \\
\mathrm{~km} / \mathrm{h}\end{array}$ & & & & 18,01 & 18,55 \\
\hline
\end{tabular}

Table 1: average stem spacing

It can be seen that in most cases the plant spacing increases as the speed increases. The phenomenon can be observed to varying degrees at each experimental site. It can be concluded that the effect is largely independent of the type of seed drills. One of the causes of this phenomenon is the increasing rate of sowing errors, which was also observed in the studies. In the speed range of 16-18 $\mathrm{km} / \mathrm{h}$, the seed drills began to become unreliable and were not able to follow the ground properly, the number of double and triple sowings increased significantly. In addition, there was an increasing number of incomplete sowings. In many cases, it was observed that at higher speeds, the seed wagon was unable to place the seed properly in the soil. Occasionally, valuable propagating material was found on the surface of the soil for several meters. It is easy to conclude that the errors caused by the increased speed and the resulting reduction in the number of emerged plants result in crop losses. 
The second table shows the number of seedlings per hectare calculated from the seedling distance, with the estimated yield loss. For simplicity, we assumed that the plants were not able to compensate for the decreased density. In reality, this is only partially true, but in the case of a suboptimal number of plants, yield loss can be expected in all cases.

\begin{tabular}{|c|c|c|c|c|c|c|c|c|c|c|c|}
\hline & \multicolumn{2}{|c|}{$\begin{array}{c}\text { Maize } \\
\text { Tura }\end{array}$} & \multicolumn{2}{|c|}{$\begin{array}{l}\text { Sunflower } \\
\text { Tápiószőlős }\end{array}$} & \multicolumn{2}{|c|}{$\begin{array}{c}\text { Sunflower } \\
\text { Simaság }\end{array}$} & \multicolumn{2}{|c|}{$\begin{array}{c}\text { Silage maize } \\
\text { Hegykő }\end{array}$} & \multicolumn{2}{|c|}{$\begin{array}{l}\text { Maize } \\
\text { Fertőd }\end{array}$} & \multirow[b]{2}{*}{ avg \% } \\
\hline & plant/ha & $\%$ & plant/ha & $\%$ & plant/ha & $\%$ & plant/ha & $\%$ & plant/ha & $\%$ & \\
\hline $\begin{array}{l}10 \\
\mathrm{~km} / \mathrm{h}\end{array}$ & 63452 & 100 & 50811 & 100 & 52243 & 100 & 79039 & 100 & 73479 & 100 & 100 \\
\hline $\begin{array}{l}12 \\
\mathrm{~km} / \mathrm{h}\end{array}$ & 61988 & 97,7 & 48117 & 94,7 & 47647 & 91,2 & 71717 & 90,7 & 67384 & 91,7 & 93,2 \\
\hline $\begin{array}{l}14 \\
\mathrm{~km} / \mathrm{h}\end{array}$ & 60201 & 94,9 & 46883 & 92,3 & 45536 & 87,2 & 71561 & 90,5 & 67556 & 91,9 & 91,36 \\
\hline $\begin{array}{l}16 \\
\mathrm{~km} / \mathrm{h}\end{array}$ & 58567 & 92,3 & 45790 & 90,1 & - & - & 75459 & 95,5 & 68541 & 93,3 & 92,8 \\
\hline $\begin{array}{l}18 \\
\mathrm{~km} / \mathrm{h}\end{array}$ & - & - & - & - & - & - & 73071 & 92,5 & 70943 & 96,5 & 94,5 \\
\hline
\end{tabular}

Table 1: Results of the experiment in the form of number of plants / hectare and percentage of yield loss

The values shown in Table 2 are the number of plants per hectare calculated from the measurements made during the experiment and their percentage of the $10 \mathrm{~km} / \mathrm{h}$ value, which we considered as $100 \%$. The relationship between the increase in speed and the increase in plant distance in the areas of Tura, Tápiószőlős is well presented. These sites were sown with 6 rows of seed drills, while in the case of the Hegykő and Fertőd fields 12 rows of seed drills were used, for which the close relationship between the development of speed and planting distance can no longer be said.

The speed of $10 \mathrm{~km} / \mathrm{h}$ was considered to be $100 \%$ in all cases, at this value the highest number of plants could be measured. At a speed of $12 \mathrm{~km} / \mathrm{h}$, the number of plants decreased by $6.8 \%$ on average. At a speed of $14 \mathrm{~km} / \mathrm{h}$, the number of plants and the yield decreased on average by $8.64 \%$. In the event of such a loss, serious consideration should be given to whether it is worth accelerating the sowing to this speed. In the $16-18 \mathrm{~km} / \mathrm{h}$ range, smaller seed drills began to become unreliable, and some proved unsuitable for use at such speeds.

The seed drills used in the experiments were most accurate at speeds of 10 and $12 \mathrm{~km} / \mathrm{h}$. At 14$16-18 \mathrm{~km} / \mathrm{h}$, the drills worked reliably, where the high coulter pressure was constantly ensured. In general, seed drills with a more robust beam structure are capable of this. In the experiments, seeders larger than 6 rows proved to be better.

\section{CONCLUSIONS}

For hungarian farmers the spring time sowing is very critical, because of the short optimal time period available for maize and sunflower. Through our experiments we explored the possibility of speeding up the process of sowing, as a solution to this problem. We found that compared to the baseline $10 \mathrm{~km} / \mathrm{h}$ speed, the increased speed caused noticeable quality problems, and density loss. The observed effects were less determinate where larger planting machines were used. These problems may lead to serious yield and economical loss, so the increased sowing speed is not an advisable option. The farmers shall consider investing into larger planting machines instead to be able to sow the spring crops in the optimal time.

\section{REFERENCES}

1. Antal, J. (2005), , Basics of Crop Production” (A növénytermesztés alapjai) Mezögazda Kiadó Budapest 89-92

2. Árendás, T., Berzsenyi, Z., Bónis, P. (2012), „Agronomic research in Martonvásár aimed at promoting field cereal production" (A szántóföldi gabonatermesztés lehetöségeinek kihasználását segítö agrotechnikai kutatások Martonvásáron.) Agrártud. Közl. 49. 89-93.

3. Berzsenyi, Z., Györffy, B. (1995), „Effect of different crop production factors on maize yield and yield stability" (Különbözö növénytermesztési tényezök hatása a kukorica termésére és termésstabilitására) Növénytermelés. 44. 5-6: 507-517

4. Berzsenyi, Z. (2005), ,Responses of maize (Zea mays L.) hybrids to sowing date, $N$ fertiliser and plant density in different years", Acta Agronomica Hungarica

5. Kovács, P., Sárvári, M. (2016), „Effect of NPK fertilization and plant number on hybrid production of different genetically based maize in a semi-industrial experiment" $\quad(A z \quad N P K$ mütrágyázás és a tőszám hatása az eltérö genetikai alapú kukorica hibridektermésére félüzemi kísérletben), Agrártudományi Közlemények, 2016/69.

6. Novák, A., Máriás, K. (2013), „Effects of sowing time on yield and oil content of different sunflower genotypes in years with different water supply", International Scholarly and Scientific Research \& Innovation 
7. Radics, L. (2012), „Sustainable Arable Crop Production 2" (Fenntartható Szemléletü Szántóföldi Növénytermesztéstan 2) Agroinform Kiadó - Budapest 57-69, 370-371

8. Szabó A., Pepó P., (2007), „Effect of plant density on yield and oil content of different sunflower genotype", Cereal Research Communications. vol. 35. no. 2. 1121-1124.

9. Hungarian Central Statistical Office, Summary data of agriculture, 2020, https://www.ksh.hu/agriculture

10. This research was carried out in connection with the establishment of the EU Innovation Task Forces and the investment required for the implementation of the innovative project in connection with the grant document number 3023661216. 